\section{Keywords}

African Americans/ Blacks

Attitude to health

Men

Neoplasms

Socioeconomic factors

\title{
Improving the health of African American men: experiences from the Targeting Cancer in Blacks (TCiB) Project
}

\author{
Jane G. Fort
}

Abstract

Background: African-American men lack knowledge of cancer facts and risk factors, and their personal attitudes and beliefs along with health care system interactions are barriers to cancer prevention. This paper highlights cancer prevention information from men in the Southeastern United States.

Methods: This community-based participatory research project surveyed 12,444 Black adult residents in Nashville and Chattanooga, Tennessee and in Atlanta and Decatur, Georgia regarding their cancer prevention knowledge, attitudes and practices. A sample (928) of 1407 men's responses was analyzed for education and income differences.

Results: Analyses found no significant differences in cancer prevention practices between men with high income and high education versus those with lower income and lower education level, but did show significant differences between education and income groups in cancer prevention knowledge and attitudes.

Conclusions: Income and education are not equal predictors of cancer prevention. Direct outreach efforts to black men of low education and income levels may be effective if interventions are tailored to separate socio-economic groups. Clear and thorough information about diseases, including their risks, prevention/detection procedures, treatment and cure are needed within the health care system itself, as well as for patients in the office, clinic, and community in innovative interactions to assist underserved men to increase and improve their knowledge, attitudes and practices regarding health promotion. (c) 2007 WPMH GmbH. Published by Elsevier Ireland Ltd.

\section{Introduction}

Jane G. Fort, PhD Department of Professional and Medical Education, Meharry Medical College, Nashville, TN, USA

E-mail:

jfort@mmc.edu

Online 3 December 2007
National statistics and reports indicate racial/ ethnic minorities more often exhibit greater disease rates than their white counterparts, raising concerns within the health care system (HCS) that have led to special efforts and recommendations to reduce, and even eliminate, racial and ethnic disparities in health [17]. Men in general, and black men in particular, are at especially high risk for disease, disability, and death; while there are continuing improvements in the health of the nation's populations, men's life expectancy at birth and at age 65 continues to be less than that of women; reports identify men as having less contact with the HCS than women, and state that when men do interact with the system, they tend to present at more advanced stages of disease and are harder to reach in intervention activities for prevention behavior discussions or practices [8-20]. 
While rates of cancer, the second leading cause of death in America, are declining in the nation, black incidence and mortality rates are greater than those for other populations [21-26]. The cancer objectives for HP2010 (Healthy People 2010) include the reduction of morbidity and mortality rates for cancers of the prostate, lung, and colonrectum, all of which black men exhibit at high rates regardless of socio-economic status. Disparities data are used to emphasize the need to create and maintain health promotion and disease prevention efforts tailored to the black community [1-5]. Research has included assessments of specific barriers Blacks may experience in prevention and treatment efforts, including daily realities such as racism and discrimination, not only experienced from society in general, but also from the HCS and its personnel [4,78,27-30].

Researchers identify barriers to screening in black men that include lack of knowledge about general cancer prevention facts and risk factors and about specific cancers, as well as attitudes, particularly those relating to components of masculine behavior [12-13,24,3036]. Additionally, screening involves patient behavioral choices that require information sufficient to facilitate informed decisions about prevention and treatment. The HCS has established detailed 'informed decisionmaking' procedures and recommendations for system-patient interactions for cancer [37]. In such efforts, the health care provider's role is cited as crucial; a provider recommendation is identified as an important, or even the determining, factor in adherence to advice for disease prevention and health promotion [38-42].

Meharry Medical College in Nashville, Tennessee and Morehouse School of Medicine in Atlanta, Georgia, two historically Black health care training institutions, implemented a community-based participatory research project as part of the National Cancer Institute program 'Cancer Prevention Awareness: The Black College as a Resource' [43-44]. The Meharry-Morehouse project sought to inform Blacks about cancer risks and risk reduction, and ascertain the factors that hinder or promote the diffusion of health information to Black and other minority populations. Choosing to address the most prevalent and pre- ventable cancers affecting Blacks, the project obtained self-reported cancer prevention knowledge, attitudes, and practices of African American/Black adults in the home states of the two institutions, Tennessee and Georgia, where cancer statistics are just as severe as those for the nation [45-47]. The project, reported elsewhere, was entitled Targeting Cancer in Blacks (TCiB) and addressed cancers of the lung, female breast, prostate, colon and cervix, along with related risk-reduction behaviors: smoking cessation, early screening, exercise and diet [48]. Mitchell considered the self-reported cancer prevention practices, knowledge, and beliefs of a subpopulation of TCiB men in relation to their education and income status; the current paper reports some of the responses of these men [49].

\section{Methods}

The TCiB project conducted surveys in 1994 and 1996 of African American/Black adults 18 years of age or older, residing in census tracts in Nashville and Chattanooga, Tennessee and in Atlanta and Decatur, Georgia with high concentrations of black adults (1990 census). Mitchell chose a cross-sectional sample from the four cities yielding 1407 men's responses to explore any differences in cancer prevention knowledge, attitudes and practices between men of low versus high income and low versus high education. He defined annual household income as low at $\$ 20,000$ or less and as high at $\$ 40,000$ or more, while low education was defined as completion of grade 12 or less of high school versus completion of college or higher degree.

The project's 'Knowledge, Attitudes, and Practices Questionnaire' was designed as a 35-minute random-digit-dial computerassisted telephone survey and was conducted by Westat, Inc., a research company in Rockville, MD. The pre- and post-intervention surveys included a demographic screener and questions to one respondent per contacted household to obtain: self-identification of respondent as Black/African American adult resident, date of birth, highest grade completed, and annual household income. Mitchell analyzed the following questions in his subsample: 
(1) Screening practices: digital rectal exam, blood stool test, proctoscopic exam

(a) Have you ever had...?

(b) Within the last 2 years, how many times have you had...by a doctor or nurse?

(2) Knowledge of cancer risk: more likely, no difference, less likely

(a) Having other family members who had cancer

(b) Eating lots of fresh fruit and vegetables

(c) Smoking cigarettes or chewing tobacco

(d) Having a lot of stress in your life

(e) Eating high fiber foods such as whole grain breads and cereals, fruits, and vegetables

(3) Attitude regarding cancer: agree, no opinion, disagree

(a) Getting cancer is a death sentence for most people

(b) If I had cancer, I would rather not know about it

(c) There are some things I can do to help me keep from getting cancer

(d) It's too late for me to start worrying about cancer now

(e) What people eat or drink doesn't affect whether they will get cancer

(f) By eating certain kinds of foods, people can make it less likely they will get cancer

\section{Results}

The TCiB respondent population of 12,444 (41$45 \%$ men) was representative of the target census tracts and was predominantly aged 18-39 years (52\%). Median household incomes ranged from $\$ 4,999$ to $\$ 29,531$ with $90 \%$ of respondents reporting a household income below $\$ 20,000 ; 39 \%$ of the survey participants reported a high school education or less. The respondent population reported having health insurance $(84 \%)$ at least partially provided by their employer (63\%) with their health care being provided at a private doctor's office (56\%) with the doctor as the usual provider (86\%). Mitchell's sample of 1407 men yielded roughly equal numbers from the four cities (Nashville: 315; Chattanooga: 325; Atlanta: 371; Decatur: 396); education and income selection criteria were met by $928(66 \%)$ of the men.

Using a Chi-square $\left(\chi^{2}\right)$ alpha level of less than 0.05 to determine significance, Mitchell found no significant differences in cancer prevention practices ('Ever had/recency of digital rectal exam, blood stool test, proctoscopic exam') between men with high income and education and those with lower income and education; they tended not to have had any procedure (see Table 1).

However, the analyses of knowledge and attitudes of TCiB men did show some signifi-

Table 1 Cancer prevention practices among high and low education and high and low income African American males 1994/1996 in Tennessee and Georgia

\begin{tabular}{|c|c|c|c|c|c|c|}
\hline & $\begin{array}{l}\text { High } \\
\text { education }\end{array}$ & $\begin{array}{l}\text { Low } \\
\text { education }\end{array}$ & $\begin{array}{l}\text { Chi square } \\
\text { education }\end{array}$ & $\begin{array}{l}\text { High } \\
\text { income }\end{array}$ & $\begin{array}{l}\text { Low } \\
\text { income }\end{array}$ & $\begin{array}{l}\text { Chi square } \\
\text { income }\end{array}$ \\
\hline & $N(\%)$ & $N(\%)$ & $\begin{array}{l}\text { Value } \\
\text { (probability) }\end{array}$ & $N(\%)$ & $N(\%)$ & $\begin{array}{l}\text { Value } \\
\text { (probability) }\end{array}$ \\
\hline \multicolumn{7}{|l|}{$\overline{\mathrm{DRE}}$} \\
\hline No, never & $11(15)$ & $99(21)$ & & $137(53)$ & $194(53)$ & \\
\hline Once in past 2 years & $27(36)$ & $124(27)$ & & $50(19.5)$ & $53(14.5)$ & \\
\hline DRE result & & & $3.99(0.273)$ & & & $3.5(0.318)$ \\
\hline \multicolumn{7}{|l|}{ BST } \\
\hline No, never & $36(50)$ & $208(52)$ & & $52(20)$ & $104(24)$ & \\
\hline Once in past 2 years & $10(14)$ & $67(17)$ & & $76(29)$ & $101(23)$ & \\
\hline BST result & & & $1.12(0.887)$ & & & $6.05(0.107)$ \\
\hline \multicolumn{7}{|l|}{ Procto } \\
\hline No, never & $41(67)$ & $183(69)$ & & $125(68)$ & 178 (71.5) & \\
\hline Once in past 2 years & $20(33)$ & $84(31)$ & & $29(16)$ & $31(12.5)$ & \\
\hline Procto result & & & $0.046(0.841)$ & & & $1.6(0.657)$ \\
\hline
\end{tabular}

DRE, digital rectal examination; BST, blood stool test; Procto, proctosigmoidoscopy. 
cant differences between education and income groups. There was no significant difference $\left(\chi^{2}=0.107\right)$ between men of higher or lower education levels regarding knowledge of cancer risk related to tobacco use ('Smoking cigarettes or chewing tobacco will make it more likely/won't make any difference/less likely you will get cancer'); both groups agreed it will make it more likely. However, significantly more men of higher income than men of lower income agreed that smoking cigarettes or chewing tobacco will make it more likely one will get cancer $\left(\chi^{2}=0.014\right)$.

TCiB men of higher income and education demonstrated greater knowledge regarding the role of family history, diet, and stressors in cancer prevention than those of lower education and income $\left(\chi^{2}<0.000-0.022\right)$. Men of lower education and lower income did not agree that having other family members who had cancer will make it more likely one will get cancer or that more fresh fruits and vegetables and whole grains in the diet will make it less likely one will get cancer, and they also were unaware of the role stress may play in increasing one's likelihood of getting cancer (see Table 2).

There was also no difference between men with higher or lower education levels in their disagreement with the attitude that 'It's too late for me to start worrying about cancer now' $\left(\chi^{2}=0.185\right)$, however, men of lower income were significantly less likely to disagree with this statement than men of higher income $\left(\chi^{2}<0.000\right)$. TCiB men of high education and income expressed more positive attitudes $\left(\chi^{2}<0.000-0.013\right)$ than those of lower education and income who agreed that getting cancer is a death sentence for most people, and who indicated they would rather not know if they had cancer. Table 3 presents the men's responses to the following attitude statements:

Table 2 Cancer prevention knowledge among high and low education and high and low income African American males 1994/1996 in Tennessee and Georgia regarding risks

\begin{tabular}{|c|c|c|c|c|c|c|}
\hline & $\begin{array}{l}\text { High } \\
\text { education }\end{array}$ & $\begin{array}{l}\text { Low } \\
\text { education }\end{array}$ & $\begin{array}{l}\text { Chi square } \\
\text { education }\end{array}$ & $\begin{array}{l}\text { High } \\
\text { income }\end{array}$ & $\begin{array}{l}\text { Low } \\
\text { income }\end{array}$ & $\begin{array}{l}\text { Chi square } \\
\text { income }\end{array}$ \\
\hline & $N(\%)$ & $N(\%)$ & $\begin{array}{l}\text { Value } \\
\text { (probability) }\end{array}$ & $N(\%)$ & $N(\%)$ & $\begin{array}{l}\text { Value } \\
\text { (probability) }\end{array}$ \\
\hline \multicolumn{7}{|c|}{ A. Smoking cigarettes or chewing tobacco } \\
\hline More likely & $76(95)$ & $604(89)$ & & $287(94)$ & $556(89)$ & \\
\hline No difference or less likely & $4(5)$ & $72(11)$ & & $19(6)$ & $70(11)$ & \\
\hline Tobacco result & & & $2.53(0.107)$ & & & $5.9(0.014)^{*}$ \\
\hline \multicolumn{7}{|c|}{ B. Having other family members who had cancer make it... } \\
\hline More likely & $60(77)$ & $346(51)$ & & $217(71)$ & $311(52)$ & \\
\hline No difference or less likely & $18(23)$ & $314(49)$ & & $89(29)$ & $284(48)$ & \\
\hline Family result & & & $16.9(0.000)^{*}$ & & & $29.2(0.000)^{*}$ \\
\hline \multicolumn{7}{|c|}{ C. Eating lots of fresh fruit and vegetables } \\
\hline More likely & $71(90)$ & $524(79)$ & & $268(87)$ & $489(79.5)$ & \\
\hline No difference or less likely & $8(10)$ & $142(21)$ & & $39(13)$ & $126(20.5)$ & \\
\hline Fruits/veg result & & & $5.5(0.017)^{*}$ & & & $8.3(0.004)^{*}$ \\
\hline \multicolumn{7}{|c|}{ D. Having a lot of stress in your life } \\
\hline More likely & $59(76)$ & $409(63)$ & & $214(72)$ & $381(63)$ & \\
\hline No difference or less likely & $19(24)$ & $244(37)$ & & $85(28)$ & $225(37)$ & \\
\hline Stress result & & & $5.2(0.022)^{*}$ & & & $6.8(0.009)^{*}$ \\
\hline \multicolumn{7}{|c|}{ E. Eating high fiber foods such as whole grain breads and cereals, fruits, and vegetables } \\
\hline More likely & $74(92.5)$ & $506(76)$ & & $277(90)$ & $471(77)$ & \\
\hline No difference or less likely & $6(7.5)$ & $162(24)$ & & $31(10)$ & $144(23)$ & \\
\hline Fiber result & & & $11.6(0.001)^{*}$ & & & $23.8(0.000)^{*}$ \\
\hline
\end{tabular}

\footnotetext{
Significance $=$ Chi-square $<0.05$.
} 
Table 3 Cancer prevention attitudes among high and low education and high and low income African American males 1994/1996 in Tennessee and Georgia regarding risks

\begin{tabular}{|c|c|c|c|c|c|c|}
\hline & $\begin{array}{l}\text { High } \\
\text { education }\end{array}$ & $\begin{array}{l}\text { Low } \\
\text { education }\end{array}$ & $\begin{array}{l}\text { Chi square } \\
\text { education }\end{array}$ & $\begin{array}{l}\text { High } \\
\text { income }\end{array}$ & $\begin{array}{l}\text { Low } \\
\text { income }\end{array}$ & $\begin{array}{l}\text { Chi square } \\
\text { income }\end{array}$ \\
\hline & $N(\%)$ & $N(\%)$ & $\begin{array}{l}\text { Value } \\
\text { (probability) }\end{array}$ & $N(\%)$ & $N(\%)$ & $\begin{array}{l}\text { Value } \\
\text { (probability) }\end{array}$ \\
\hline \multicolumn{7}{|c|}{ A. It's too late for me to start worrying about cancer now } \\
\hline Disagree & $70(87.5)$ & $557(82)$ & & $292(94.5)$ & $516(81.5)$ & \\
\hline No opinion or agree & $10(12.5)$ & $126(18)$ & & $17(5.5)$ & $117(18.5)$ & \\
\hline Late result & & & $1.8(0.185)$ & & & $28.8(0.000)^{*}$ \\
\hline \multicolumn{7}{|c|}{ B. Getting cancer is a death sentence for most people } \\
\hline Disagree & $51(64)$ & $268(47)$ & & $192(62)$ & $243(38)$ & \\
\hline No opinion or agree & $29(36)$ & $416(53)$ & & $116(38)$ & $391(62)$ & \\
\hline Death result & & & $17.7(0.000)^{\star}$ & & & $48.2(0.000)^{*}$ \\
\hline \multicolumn{7}{|c|}{ C. If I had cancer, I would rather not know about it } \\
\hline Disagree & $72(90)$ & $479(70)$ & & $249(81)$ & $454(72)$ & \\
\hline No opinion or agree & $8(10)$ & $205(30)$ & & $60(19)$ & $180(28)$ & \\
\hline Know result & & & $14.2(0.000)^{\star}$ & & & $8.70(.003)^{*}$ \\
\hline \multicolumn{7}{|c|}{ D. There are some things I can do to help me keep from getting cancer } \\
\hline Disagree & 75 (95) & $574(85)$ & & $284(92)$ & $539(86)$ & \\
\hline No opinion or agree & $4(5)$ & $103(15)$ & & $25(8)$ & $87(14)$ & \\
\hline I can do result & & & $5.9(0.013)^{*}$ & & & $6.6(0.009)^{*}$ \\
\hline \multicolumn{7}{|c|}{ E. What people eat or drink doesn't affect whether they will get cancer } \\
\hline Disagree & $67(86)$ & $460(68)$ & & $260(84)$ & $440(70)$ & \\
\hline No opinion or agree & $11(14)$ & $220(32)$ & & $48(16)$ & $189(30)$ & \\
\hline Eat/drink result & & & $11(0.001)^{\star}$ & & & $22.9(0.000)^{*}$ \\
\hline \multicolumn{7}{|c|}{ F. By eating certain kinds of foods, people can make it less likely they will get cancer } \\
\hline Disagree & $75(95)$ & $503(74)$ & & $274(89)$ & $467(74)$ & \\
\hline No opinion or agree & $4(5)$ & $179(26)$ & & $35(11)$ & $162(26)$ & \\
\hline Foods result & & & $17.4(0.000)^{\star}$ & & & $26(0.000)^{\star}$ \\
\hline
\end{tabular}

* Significance $=$ Chi-square $<0.05$.

- It's too late for me to start worrying about cancer now.

- Getting cancer is a death sentence for most people.

- If I had cancer, I would rather not know about it.

- There are some things I can do to help me keep from getting cancer.

- What people eat or drink doesn't affect whether they will get cancer.

- By eating certain kinds of foods, people can make it less likely they will get cancer.

\section{Discussion}

Mitchell's results indicate, as do those of other researchers, that economic level impacts health [1-20,35]. Lack of insurance is cited as having the greatest negative impact on health care quality and access, an impact greater than race, ethnicity, income, or education [7]. Early reports suggested that there are cultural and economic barriers to prevention, and that lower socioeconomic status, especially when measured by census tract population density, can determine cancer morbidity and mortality in prostate cancer screening of black men $[18,29]$. Among other factors, income has been a stable predictor of adherence to colorectal cancer (CRC) screening practices since 2000; some consider income the most predictive of various demographic factors in prostate cancer screening [50-53]. However, some researchers report that, with regard to physician's visits, women were the ones affected by 
income level; men tend to be more affected by non-financial barriers such as time $[24,54,55]$.

Lack of employer or public health insurance is cited as a barrier to health care, however, reports identify men as 'absent' from health care services, especially preventive procedures, even when they have comprehensive, affordable, health insurance $[10,13,30,56-59]$. Reports indicate men are not being given information about cancer or about screening procedures to help prevent it even when they interact with the HCS for annual physicals and for periodic procedures, although knowledge of factors regarding cancer is cited as facilitating men's adherence to cancer prevention $[24,30,42]$. Richardson et al. suggest that knowledge is the most important factor in cancer prevention, reporting that even when men recognized family history as a risk factor for prostate cancer, the men thought they, themselves, were immune if their father, brother, or grandfather had not experienced the disease, proposing that accurate knowledge will de-bunk myths, allowing the development of positive attitudes which will then lead to protective health behaviors [32]. Chan and others feel men must be provided with sufficient information from a trusted source in order to make appropriate informed decisions about prostate cancer treatment in concert with their physician $[34,60]$. TCiB men with low income evidenced less knowledge than did men of higher income about well-known risk factors for cancer, including tobacco use, considered the most important and best-documented cancer risk, disagreeing that smoking cigarettes or chewing tobacco would increase one's risk of cancer.

Prostate cancer screening using the prostate specific antigen (PSA) test is recommended now for populations at high risk such as black men, unlike in the middle 1990s when the TCiB data were obtained [1,3,22,61-63]. Black men receive the PSA test at lower rates than their white American counterparts, generating numerous theories and projects to identify the cause of lower rates of service and adherence $[30,50]$. The TCiB survey did not inquire about the PSA, but about three other cancer screening procedures; Mitchell reported no significant difference in screening rates for digital rectal examination (DRE), blood stool test (BST), or proctosigmoidoscopy (procto) between high and low levels of income or education among adult black men in Tennessee and Georgia. Education and income status appear not to determine TCiB men's actual behaviors regarding cancer prevention.

Patient personal traits, for example, their attitudes and beliefs, and even demographic qualities such as marital status, are also noted as facilitators and as barriers to screening. $[25,32]$. Many of the challenges found in providing men with competent health care and in supporting their adoption of recommended practices are similar to those found with other underserved sub-populations and are related to the attitudes held, including distrust, diminished self-esteem, and avoidance of condescending treatment from the HCS $[24,64-$ 66]. Additionally, researchers find that men's ideas of masculinity interfere with the adoption of healthy behaviors $[12,13,36]$. TCiB men of low education and income expressed significantly more attitudes that are associated with poor health outcomes, agreeing that cancer is a death sentence for most people, and that if they had cancer they would rather not know about it; they also disagreed that there are things they can do to help avoid cancer.

For men, recommendations are made for innovations that expand the range of strategies beyond even the comprehensive community health center to include use of non-health care settings including embracing off-site outpatient venues and approaches $[26,36,55,67-$ 69]. Patients who prefer to make independent health care decisions may respond best to interventions that are external to the HCS rather than to ones provided by health care personnel [70]. Including client-provider opportunities to discuss risks and benefits of screening procedures being recommended or offered, is a practice some consider an especially important affirmation of men's sense of autonomy $[37,71,72]$.

The HCS currently advocates developing partnerships or collaborations with community organizations and institutions to facilitate adherence to healthy lifestyles; consideration of the various possibilities may lead to greater successes $[73,74]$. TCiB established and maintained broad-based relationships across the community with businesses, organizations, institutions and individuals and partnered with fraternities to reach educated men, who, in turn, participate in service projects that involve less well-educated and younger 
men. Those active in their fraternity were usually also active in faith institutions. Such men were willing to recommend innovative approaches for the content and structure of outreach activities, like their annual Men's Day observance, and encouraged increased screening and behavior change for other men and for the women in their families, as well.

Researchers have established partnerships with local churches that serve the communities for which interventions are tailored and subsequently observed improved health practices $[60,75]$. While religious involvement improves health care practices, TCiB found many more survey respondents indicated their source of cancer prevention information was the print and electronic media $[48,76]$. In Nashville, a transportation bus painted with project messages traveling throughout the community was identified as the source of cancer prevention information for as many respondents as identified the various HCS entities, and for even more than identified any of the community entities like family/friends, worksite, health fairs, church, community group, hairstylists [77].

TCiB attempted to partner with local barbershops to provide information to their clients as had been successful with the project women through the local beautician's union. However, greater success was experienced through direct independent contact with individual owners than through the barbers' organizational structure. Barbershops may prove valuable since they are locales where men already dialog among themselves about many issues $[78,79]$. Discussion of sensitive health topics such as beliefs and behavior may be more acceptable when presented by familiar figures and in less intimidating 'men only' surroundings and interactions than those of the HCS $[80,81]$.

The most important result from the Institute of Medicine report, Unequal Treatment, may be Finding 3-1 indicating the health care system itself as contributing to the nation's current health disparities as a result of lack of, or limited, access to its procedures, services, acceptable standards of quality, and materials [2]. Research shows that the health care provider's recommendation for screening is important, and possibly the crucial factor in patient adherence to health promotion practices $[5,38$, $40,41,59,72,82-86]$.

Advocating that providers share information with their patients also requires acknowl- edging the need for and providing support to providers' efforts to stay abreast of prevention information and issues regarding sub-populations at increased risk, specific risk factors, and system and community resources that support identified risk reduction activities $[7,8,37,67$, 86]. McFall noted that discussion of risks and benefits were more likely when the PSA test was being recommended and more likely with African American men, but not necessarily with more educated men, denoting an increased awareness among providers of the risk for African Americans and men of low education [72]. CRC screening options present a particularly challenging set of decisions regarding recommendation, for the option advocated could lead to increases rather than decreases in ethnic and economic disparities, particularly if the preferred or recommended method is expensive [87-89].

\section{Summary Recommendations and Implications}

In the final analysis, the responsibility remains with the HCS itself to see that men's health care practices improve, particularly for diseases such as cancer, heart disease and diabetes, where personal behaviors play a major role in prevention and treatment. Communitybased health services may be particularly successful, especially when provided in non-traditional formats and venues by a usual source of care - a provider who is sensitive to the cultural nuances of the patient and who makes recommendations for appropriate prevention practices. The Sullivan Commission's report, Missing Persons, recommends that one important means of gaining health equity could come from increased access through augmenting the nation's health care workforce to include caring, culturally-sensitive providers in addition to its physicians [90]. Nurse practitioners, physician assistants, as well as registered nurses, dietitians, social workers and also para-professionals, system navigators, lay health or community outreach workers or advisors, all can make valuable contributions on a prevention team to augment coordinated care. Services provided by these professionals may free additional time for the primary provider (preferred by the TCiB population) to interact with a patient allowing 
communication of essential information about findings, risks, and possible recommended treatments. Utilizing such opportunities can result in screening and services that might not otherwise occur and consequently facilitate men's positive interactions with the system $[24,65,91-93]$.

Special efforts are being mounted to improve men's health status ranging from assertive outreach within and outside of the system, through modification of screening guidelines for those most at risk, to partnering with social and political entities that increase attention and action on policies affecting communities [4,5,94-110]. Capitalizing on men's attraction to technology and coupling it with the national and international growth of the Internet may prove a valuable innovation to capture men's interest and attention; 'patient-friendly' websites are increasingly available $[68,111-116]$.

The national HCS has embraced its responsibility to improve the health status of the country's citizens, especially those in the most vulnerable sub-populations, and is undergoing significant change. Summaries of evidencebased approaches are increasingly available for the implementation of clinical practice modifications $[63,82,87,88,117,118]$. Put Prevention Into Practice (PPIP) encourages a review of one's own as well as patients' values and beliefs, an assessment of the practices currently offered and implemented, incorporation of specific prevention services delivered, and recommendations for the evaluation of successes and challenges [119]. Such features are all part of the health care system's program of objectives for growth and implementation and are identified as priorities considered essential elements in successful outreach to men, especially men of color, and particularly black men [3,5,120-127].

Advocating and establishing partnerships with others seeking changes in societal laws and regulations may be the most important actions for the nation's health care system to observe healthier citizen behaviors while it continues to work to increase and improve knowledge and to alter attitudes and beliefs both within and outside of the health care disciplines. The success of the system's efforts to improve and expand its services will determine when and to what extent men's health practices and status, particularly those of black men, demonstrate improvement.

Limitations of this study arise from the error inherent in its reliance on self-report recalled information and on the characteristics of random-digit-dial survey procedures. The sample, while representative of the populations of the four cities, does not represent urban populations of the nation as a whole or of other areas with predominantly black residency as geographical comparisons of health status indicate.

\section{Acknowledgements}

The National Cancer Institute funded the TCiB Cancer Prevention and Awareness Program project as Contract N01-C094394. The author appreciates the comments and recommendations made by the journal reviewers and editors.
References

[1] U.S. Department of Health and Human Services, Public Health Service. Healthy People 2000: National Health Promotion and Disease Prevention Objectives. Washington: US Government Printing Office; 1991.

[2] Smedley BD, Stith AY, Nelson AR, editors. Unequal Treatment: Confronting Racial and Ethnic Disparities in Health Care. Washington, DC: National Academy Press; 2002. Available at: http://www.nap.edu/ catalog/10260.html. Accessed 17-May-07.

[3] U.S. Department of Health and Human Services. Healthy People 2010: Objectives for Improving Health. McLean, VA: International Medical Publishing, Inc.; 2000.

[4] U.S. Dept of Health and Human Services. Healthy People 2010 Progress Reviews.
Available at: http://www.healthypeople.gov /Data/PROGRVW/default.htm\#Population. Accessed 17-May-07.

[5] U.S. Department of Health and Human Services. Healthy People 2010 Midcourse Review. Available at: http://www. healthypeople.gov/data/midcourse/default.htm. Accessed 17-May-07.

[6] National Center for Health Statistics. Health, United States 2006 with Chartbook on Trends in the Health of Americans. Hyattsville, MD: NCHS; 2006. Available at: http://www.cdc.gov/nchs/hus/hus06.pdf. Accessed 17-May-07.

[7] Agency for Healthcare Research and Quality. 2006 National Healthcare Disparities Report. Rockville, MD: U.S. Department of Health and Human Services, Agency for Healthcare Research and Quality; 2006. Available at: http://www.ahrq.gov/ qual/nhdr06/nhdr06report.pdf. Accessed 17-May-07.

[8] Agency for Healthcare Research and Quality. National Healthcare Quality Report. Rockville, MD: U.S. Department of Health and Human Services, Agency for Healthcare Research and Quality; 2006. Available at: http://www.ahrq.gov/qual/nhqr06/ nhqr06report.pdf. Accessed 17-May-07.

[9] Braithwaite RL. The health status of black men. In: Braithwaite RL, Taylor SE, editors. Health Issues in the Black Community. 2nd edn San Francisco: Jossey-Bass; 2001. p. 62-80. 
[10] Satcher D. Overlooked and underserved: improving the health of men of color. Am J Public Health 2003;93:707-9.

[11] Gadson SL. The third world health status of black American males. J Natl Med Assoc 2006;98:488-91.

[12] Bonhomme JJ. The health status of AfricanAmerican men: improving our understanding of men's health challenges. jmhg 2004;1:142-6.

[13] Bonhomme JJ. State of men's health: a national perspective. Men's Health Network \& National Black Men's Health Network. Presentation to Tennessee Symposium on Men's Health, 2006 Sep 28. Available at: http://www.menshealthnetwork.org. Accessed 17-May-07.

[14] Williams DR. The health of men: structured inequalities and opportunities. Am J Public Health 2003;93:724-31.

[15] Treadwell HM, Ro M. Poverty, race, and the invisible men. Am J Public Health 2003;93:705-7.

[16] Sandman D, Simantov E, An C. Out of Touch: American Men and the HCS. Publication No. 374. New York: The Commonwealth Fund; 2000. Available at: http://www.cmwf.org/usr_doc/sandman_ outoftouch_374.pdf. Accessed 17-May-07.

[17] Rumm PD. Mass communication and social marketing strategies to improve men's health. jmhg 2005;2:121-3.

[18] Baquet CR. Cancer Among Blacks and Other Minorities: Statistical Profiles. National Institutes of Health Publication Number 86-2875. Washington: U.S. Government Printing Office; 1986.

[19] Hardy RE, Hargreaves MK. Cancer prognosis in black Americans: a mini-review. J Natl Med Assoc 1991;83:574-9.

[20] Wu LY, Semenya KA, Hardy RE, Hargreaves MK, Robinson SB, Pederson L, et al. Cancer rate differentials between blacks and whites in three metropolitan areas: a 10-year comparison. J Natl Med Assoc 1998;90:410-6.

[21] American Cancer Society. Cancer Facts \& Figures 2007. Atlanta: American Cancer Society; 2007. Available at: http ://www. cancer.org/downloads/STT/ CAFF2007PWSecured.pdf. Accessed 17-May-07.

[22] American Cancer Society. Cancer Facts \& Figures for African Americans 2007-2008. Atlanta: American Cancer Society; 2007. Available at: http://www.cancer.org/ downloads/STT/CAFF2007AAacspdf2007. pdf. Accessed 17-May-07

[23] Jemal A, Siegel R, Ward E, Murray T, Xu J, Thun MJ. Cancer statistics, 2007. CA Cancer J Clin 2007:57:43-66.

[24] Whitley EM, Samuels BA, Wright RA, Everhart RM. Identification of barriers to healthcare access for underserved men in Denver. jmhg 2005;2:421-8.
[25] Consedine NS, Morgenstern AH, KudadjieGyamfi E, Magai C, Neugut Al. Prostate cancer screening behavior in men from seven ethnic groups: the fear factor. Cancer Epidemiol Biomarkers Prev 2006; 15:228-37.

[26] Partl EM. Who is healing the homeless? jmhg 2005;2:270-2.

[27] Williams DR, Collins C. Racial residential segregation: a fundamental cause of racial disparities in health. Public Health Rep 2001;116:404-16.

[28] Baquet CR, Horm JW, Gibbs T, Greenwald $P$. Socioeconomic factors and cancer incidence among blacks and whites. I Natl Cancer Inst 1991;83:551-7.

[29] Freeman H. Race, poverty, and cancer. J Natl Cancer Inst 1991:83:526-7.

[30] Ford ME, Vernon SW, Havstad SL, Thomas SA, Davis SD. Factors influencing behavioral intention regarding prostate cancer screening among older African-American men. J Natl Med Assoc 2006;98:505-14.

[31] Anon. Black Americans' attitudes towards cancer and cancer tests: highlights of a study. CA Cancer J Clin 1981;31:212-8.

[32] Richardson JT, Webster JD, Fields NJ. Uncovering myths and transforming realities among low-SES African-American men: implications for reducing prostate cancer disparities. J Natl Med Assoc 2004;96:1295-302.

[33] Fort JG. African American cancer myths. J Natl Med Assoc 2006;98:992.

[34] Chan ECY, Vernon SW, O'Donnell F, Ahn C, Greisinger A, Aga DW. Informed consent for cancer screening with prostatespecific antigen: how well are men getting the message? Am J Public Health 2003;93:779-85.

[35] Lawsin C, DuHamel K, Weiss A, Rakowski W, Jandorf L. Colorectal cancer screening among low-income African Americans in East Harlem: a theoretical approach to understanding barriers and promoters to screening. J Urban Health 2006;84:32-44.

[36] Gough B. Try to be healthy, but don't forgo your masculinity: deconstructing men's health discourse in the media. Soc Sci Med 2006:63:2476-88.

[37] Centers for Disease Control and Prevention. Guide to Community Preventive Services: Systematic Preventive Evidence-Based Recommendations. Cancer. Atlanta, GA National Center for Health Marketing; 2007. Available at: http://www.thecommunityguide.org/cancer/idm/ default.htm. Accessed 17-May-07.

[38] Ossip-Klein DJ, McIntosh S, Utman C, Burton K, Spada J, Guido J. Smokers ages 50+ who gets physician advice to quit? Prev Med 2000:31:364-9.

[39] Klabunde CN, Riley GF, Mendelson MT, Frame PS, Brown MI. Health plan policies and programs for colorectal cancer screening: a national profile. Am J Manag Care 2004;10:273-9.

[40] Finney Rutten LJ, Meissner HI, Breen N, Vernon SW, Rimer BK. Factors associated with men's use of prostate-specific antigen screening: evidence from Health Information National Trends Survey. Prev Med 2005:40:461-8.

[41] Haggerty J, Tudiver F, Brown JB, Herbert C, Ciampi A, Guibert R. Patients' anxiety and expectations: how they influence family physicians' decisions to order cancer screening tests. Can Fam Physician 2005;51:1658-9.

[42] Wender RC. Preserving primary care: the front line in the war against cancer. CA Cancer J Clin 2007;57:4-5.

[43] National Cancer Institute. Cancer Prevention Awareness Program for Black Americans. Washington: Office of Cancer Communications; 1985.

[44] National Cancer Institute. Cancer Prevention Awareness Program for Black Americans: A Report to the Director. Washington: Office of Cancer Communications; 1986

[45] Tennessee Cancer Coalition. Tennessee Comprehensive Cancer Control Plan for 2005-2008. Nashville, TN: National Comprehensive Cancer Control Program, Centers for Disease Control and Prevention, Tennessee Department of Health Comprehensive Cancer Control Program; 2005. Available at: http://health.state.tn.us/CCCP/ TCCC_Plan.pdf. Accessed 8-Oct-07.

[46] Tennessee Department of Health. Health of Tennessee's Men 2005: A Summary Report of Mortality and Men's Health Issues. Nashville, TN: Division of Health Statistics; 2006. Available at: http:// health.state.tn.us/statistics/PdfFiles/ TNMen2005.pdf. Accessed 8-Oct-07.

[47] Singh S, Bayakly AR, McNamara C, Redding K, Thompson SK, Wall K. Georgia Cancer Data Report 2005. Pub No. DPH06/007HW. Atlanta, GA: Georgia Department of Human Resources, Division of Public Health, Chronic Disease, Injury, and Environmental Epidemiology Section, and the American Cancer Society, Southeast Division; 2006. Available at: http:// health.state.ga.us/pdfs/chronic/cancer/GA_ Cancer_Report_2005.pdf. Accessed 17May-07.

[48] Blumenthal DS, Fort JG, Ahmed NU, Semenya KA, Schreiber GB, Perry S, et al. Impact of a two-city community cancer prevention intervention on African-Americans. J Natl Med Assoc 2005:97:1479-88.

[49] Mitchell R, IV. Cancer Prevention Knowledge, Beliefs and Practices in Selected African American Males of Low and High Economic Status. Dissertation. Nashville, 
TN: School of Graduate Studies and Research, Meharry Medical College; 1996.

[50] Breen N, Meissner HI. Toward a system of cancer screening in the United States: trends and opportunities. Annu Rev Public Health 2005;26:561-8.

[51] Anger JT, Maliski SL, Krupski TL, Kwan L, Gore JL, Fink $A$, et al. Outcomes in men denied access to a California public assistance program for prostate cancer. Public Health Rep 2007:122:217-23.

[52] Woods VD, Montgomery SB, Herring $P$, Gardner RW, Stokols D. Social ecological predictors of prostate-specific antigen blood test and digital rectal examination in Black American men. J Natl Med Assoc 2006;98:492-504.

[53] Liang SY, Phillips KA, Nagamine M, Ladabaum U, Haas JS. Rates and predictors of colorectal cancer screening. Prev Chronic Dis [serial online] 2006; 3:A117. Available at: http://www.cdc.gov/pcd/issues/2006/ oct/06_0010.htm. Accessed 17-May-07.

[54] Xu KT, Borders TF. Gender, health, and physician visits among adults in the United States. Am J Public Health 2003; 93:1076-9.

[55] Oliffe J, Mróz L. Men interviewing men about health and illness: ten lessons learned. jmhg 2005;2:257-60.

[56] Agho AO, Lewis MA. Correlates of actual and perceived knowledge of prostate cancer among African Americans. Cancer Nurs 2001:24:165-71.

[57] Head J. Health News. Missing men: when it's time to visit the doctor; too few males "man up." Healthy Living 2007; Spring: 7-8. Available at: http://www.nmanet. org/images/uploads/Publications/NMAHL Spring07.pdf.

[58] O'Malley AS, Forrest CB, Feng S, Mandelblatt J. Disparities despite coverage: gaps in colorectal cancer screening among Medicare beneficiaries. Arch Intern Med 2005; 165:2129-35.

[59] Klabunde CN, Schenck AP, Davis WW. Barriers to colorectal cancer screening among Medicare consumers. Am J Prev Med 2006;30:313-9.

[60] Mitchell-Beren ME, Dodds ME, Choi KL, Waskerwitz TR. A colorectal cancer prevention, screening, and evaluation program in community black churches. CA Cancer J Clin 1989;39:115-8.

[61] U.S. Preventive Services Task Force. Screening for Prostate Cancer: Recommendation and Rationale. Ann Intern Med 2002;137:915-6.

[62] American Cancer Society. Screening guidelines for the early detection of cancer in asymptomatic people. In: Cancer Prevention and Early Detection Facts and Figures 2007. Atlanta: American Cancer Society; 2007. Available at: http://www.cancer.
org/downloads/STT/CPED2007PWSecured. pdf. Accessed 17-May-07.

[63] Blumenthal DS. 'Best science' for the reduction of disparities in cancer. Ethn Dis 2003;13(Suppl 3):S3-67-72.

[64] Cruz A, Murphy F, Nyarko N, Yung Krall DN. The view from the community. In: Blumenthal DS, DiClemente RJ, editors. Community-based Health Research: Issues and Methods. New York, NY: Springer; 2004. p. 63-80

[65] Ahmed NU, Fort JG, Micah TH, Dickerson $P$, Belay $Y$. Needed change in the health care system: perspectives of lay health workers. J Ambul Care Manage 2006;29:17-23.

[66] Dawson G. Our race is not the problem. J Natl Med Assoc 2006:98:1203-4.

[67] Management Sciences for Health. African Americans and cancer. In: The Provider's Guide to Quality and Culture. Cambridge, MA: MSH with Health Resource and Services Administration, Office of Minority Health and Bureau of Primary Health Care. Available at: http://erc.msh.org/provider/ informatic/AA_Cancer.pdf. Accessed 15May-07.

[68] Men's Health Network. Best practices for men's health programs: The United States and Australia. Tennessee Symposium on Men's Health. Nashville, TN: MHN: 2006

[69] Sadovsky R. Men's healthcare needs improvement: a recommendation for a midlife men's health assessment visit. jmh 2005;2:375-81.

[70] Messina CR, Lane DS, Grimson R. Colorectal cancer screening attitudes and practices: preferences for decision making. Am J Prev Med 2005;28:439-46.

[71] Wolff M, Bates T, Beck B, Young S, Ahmed SM, Maurana C. Cancer prevention in underserved African American communities: barriers and effective strategies - a review of the literature. WM 2003:102:36-40.

[72] McFall SL. US men discussing prostate-specific antigen tests with a physician. Ann Fam Med 2006;4:433-6.

[73] U.S. Department of Health and Human Services. Focus Area 7: Educational and community-based programs. In: Healthy People 2010: Objectives for Improving Health. McLean, VA: International Medical Publishing, Inc.; 2000

[74] U.S. Dept. of Health and Human Services. Focus Area 3. Cancer. In: Healthy People 2010 Midcourse Review. Published online, 2007. Available at: http://www.healthy people.gov/data/midcourse/pdf/FA03.pdf. Accessed 17-May-07.

[75] Katz ML, James AS, Pignone MP, Hudson MA, Jackson E, Oates $V$, et al. Colorectal cancer screening among African
American church members: a qualitative and quantitative study of patient-provider communication. BMC Public Health 2004; 4:62.

[76] Aaron KF, Chesley Jr FD. Beyond rhetoric: what we need to know to eliminate disparities. Ethn Dis 2003;13(Suppl 3):S3-9S3-11.

[77] Fort JG. Sources of cancer information. J Natl Med Assn 2006;98(6):993.

[78] Hart Jr A, Bowen DJ. The feasibility of partnering with African-American barbershops to provide prostate cancer education. Ethn Dis 2004;14:269-73.

[79] Linnan LA, Holt CL. Using Barbers as Peer Educators to Convey Information on Early Detection of Cancer. Atlanta, GA: Department of Health and Human Services, Centers for Disease Control and Prevention; 2006. Available from http://www.cdc.gov/ $\mathrm{prc} /$ research - projects/special-interestprojects / barbers - peer-educators-earlydetection-cancer.htm. Accessed 17-May07.

[80] Magnus M. Prostate cancer knowledge among multiethnic black men. I Natl Med Assoc 2004;96:650-9.

[81] Wilkins D. 'Getting it sorted': identifying and implementing practical solutions to men's health. jmhg 2005;2:13-6.

[82] National Center for Health Marketing, Community Guide Partners. Guide to Community Preventive Services: Systematic Preventive Evidence-Based Recommendations. Seven Ways Physicians Can Improve the Delivery of Preventive Care to Their Patients: Health Systems Recommendations from the Guide to Community Preventive Services. Atlanta, GA: Centers for Disease Control and Prevention. Available at: http://www.thecommunityguide. org/library/physicians.pdf. Accessed 17May-07.

[83] Taylor V, Lessler D, Mertens K, Tu SP, Hart A, Chan N, et al. Colorectal cancer screening among African Americans: the importance of physician recommendation. J Natl Med Assoc 2003;95:806-12.

[84] Gilbert A, Kanarek N. Colorectal cancer screening: physician recommendation is influential advice to Marylanders. Prev Med 2005;41:367-79.

[85] James TM, Greiner KA, Ellerbeck EF, Feng C, Ahluwalia JS. Disparities in colorectal cancer screening: a guideline-based analysis of adherence. Ethn Dis 2006;16:22833.

[86] Klabunde CN, Frame PS, Meadow A, Jones E, Nadel M, Vernon SW. A national survey of primary care physicians' colorectal cancer screening recommendations and practices. Prev Med 2003:36:352-62.

[87] Screen for Life; National Colorectal Cancer Action Campaign. Health Professionals 
Facts on Screening: Colorectal Cancer. CDC Pub \#099-6487. Atlanta, GA: Centers for Disease Control and Prevention; 2000. Available at: http://www.cdc.gov/cancer/ colorectal/pdf/fs-professional.pdf. Accessed 16-May-07.

[88] Agency for Healthcare Research and Quality. Screening for Colorectal Cancer: Summary of Recommendations. Rockville, MD: U.S. Preventive Services Task Force; 2002. Available at: http://www.ahrq.gov/clinic/ uspstf/uspscolo.htm. Accessed 24-May07.

[89] Meissner HI, Breen N, Klabunde CN, Vernon SW. Patterns of colorectal cancer screening uptake among men and women in the United States. Cancer Epidemiol Biomarkers Prev 2006;15:389-94.

[90] The Sullivan Commission. Missing Persons: Minorities in the Health Professions: A Report of the Sullivan Commission on Diversity in the Healthcare Workforce. Durham, NC: Duke University; 2004. Available at: http://minority-health.pitt.edu/archive/ 00000040/01/Sullivan_Final_Report_000. pdf. Accessed 17-May-07.

[91] Sansbury LB, Klabunde CN, Mysliwiec P, Brown ML. Physicians' use of nonphysician healthcare providers for colorectal cancer screening. Am J Prev Med 2003;25:17986.

[92] Shaheen NJ, Crosby MA, O'Malley MS, Murray SC, Sandler RS, Galanko JA, et al. The practices and attitudes of primary care nurse practitioners and physician assistants with respect to colorectal cancer screening. Am J Gastroenterol 2000;95: 3259-65.

[93] Parham G, Hardy C, White-Johnson F. Strategies for community participation in cancer prevention. Ethn Dis 2003;13(Suppl 3): S3-73-5.

[94] Gornick ME. A decade of research on disparities in Medicare utilization: lessons for the health and health care of vulnerable men. Am J Public Health 2003;93: 753-9.

[95] Treadwell HM, Braithwaite K. Men's health: a myth or a possibility?. jmhg 2005;2:382-6.

[96] Satcher D. Ethnic disparities in health: the public's role in working for equality. Plos Med 2006;3:1683-5.

[97] Sirovich BE, Schwartz LM, Woloshin S. Screening men for prostate and colorectal cancer in the United States: does practice reflect the evidence? JAMA 2003;289: 1414-20.

[98] McBride CM, Emmons KM, Lipkus IM. Understanding the potential of teachable moments: the case of smoking cessation. Health Educ Res 2003;18:156-70.

[99] Hyman D. Reorganizing health systems to promote best practice medical care, patient self-management, and family-centered care for childhood asthma. Ethn Dis 2003;13(Suppl 3):S3-94-8.

[100] Winickoff JP, Buckley VJ, Palfrey JS, Perrin JM, Rigotti NA. Intervention with parental smokers in an outpatient pediatric clinic using counseling and nicotine replacement. Pediatrics 2003;112:1127-33.

[101] Carlos RC, Fendrick AM. Improving cancer screening adherence: using the "teachable moment" as a delivery setting for educational interventions. Am J Manag Care 2004; 10:247-8.

[102] Gorin AA, Phelan S, Hill JO, Wing RR. Medical triggers are associated with better short- and long-term weight loss outcomes. Prev Med 2004;39:612-6.

[103] Carlos RC, Underwood W, Fendrick AM, Bernstein SJ. Behavioral associations between prostate and colon cancer screening. J Am Coll Surg 2005;200: 216-23.

[104] Warner DO. Preoperative smoking cessation: the role of the primary care provider. Mayo Clin Proc 2005;80:252-8.

[105] Gritz ER, Fingeret MC, Vidrine DJ, Lazev $A B$, Mehta NV, Reece GP. Successes and failures of the teachable moment: smoking cessation in cancer patients. Cancer 2006;106:17-27.

[106] U.S. Dept. of Health and Human Services. Focus Area 11: Health communication. In: Healthy People 2010 Midcourse Review. Published online. Available at: http:// www.healthypeople.gov/data/midcourse/ pdf/FA11.pdf. Accessed 17-May-07.

[107] Powe BD, Daniels EC, Finnie R. Comparing perceptions of cancer fatalism among African American patients and their providers. J Am Acad Nurse Pract 2005;17:31824.

[108] Schmid Mast M. Dominance and gender in the physician-patient interaction. jmhg 2004; 1:354-8.

[109] Houston TK, Scarinci IC, Person SD, Greene PG. Patient smoking cessation advice by health care providers: the role of ethnicity, socioeconomic status, and health. Am J Public Health 2005;95:1056-61.

[110] Kaluzny AD. Prevention and control research within a changing health care system. Prev Med 1997;26:S31-5.

[111] Jadad AR, Meryn S. The future of men's health: trends and opportunities to watch in the age of the Internet. jmhg 2005; 2:124-8.

[112] U.S. Department of Health and Human Services. Healthy People 2010 Companion Web Sites and Documents. Published online. Available at: http://www.healthy people.gov/Implementation/compdocs. htm\#Companion. Accessed 24-May-07.

[113] Centers for Disease Control and Prevention. Your Online Source for Credible
Health Information. Atlanta, GA: CDC; 2007. Available at: http://www.cdc.gov. Accessed 24-May-07.

[114] Centers for Disease Control and Prevention. Racial and Ethnic Approaches to Community Health - REACH. Atlanta, GA: CDC; 2007. Available at: http://www.cdc.gov/ reach/. Accessed 24-May-07.

[115] U.S. Department of Health and Human Services. Office of Disease Prevention and Health Promotion. Healthfinder.gov: Your Guide to Reliable Health Information. Available at: http://www.healthfinder.gov/ . Accessed 24-May-07.

[116] Medical Library Association. For Health Consumers: "Top Ten" Most Useful Websites. Chicago, IL: Medical Library Association; 2007. Available at: http://mlanet.org/ resources/medspeak/topten.html.

Accessed 24-May-07.

[117] American Medical Association. Research Findings and Recommendations. Chicago, IL: American Medical Association; 2007. Available at: http://www.ama-assn.org/ ama/pub/category/10243.html. Accessed 17-May-07.

[118] American Medical Association. Eliminating Health Disparities. Chicago, IL: American Medical Association; 2005. Available at: http://www.ama-assn.org/ama/pub/ category/7639.html. Accessed 17-May-07.

[119] Agency for Healthcare Research and Quality. Put Prevention into Practice. A Step-bystep Guide to Delivering Clinical Preventive Services: A Systems Approach. Rockville, MD: AHRQ; 2002. Available from http:// www.ahrq.gov/ppip/manual.pdf. Accessed 17-May-07..

[120] Peters KE, Elster AB. Roadmaps for Clinical Practice: A Primer on Population-based Medicine. Atlanta, GA: American Medical Association; 2002. Available at: http://www. ama-assn.org/ama1/pub/upload/mm/433/ roadmaps_rev.pdf. Accessed 18-May-07.

[121] National Guideline Clearinghouse. Preventing Cancer, Cardiovascular Disease, and Diabetes: A Common Agenda for the American Cancer Society, the American Diabetes Association, and the American Heart Association. Dallas, TX: American Heart Association. Available at: http:// www.guideline.gov/summary/summary. aspx?doc_id=5620. Accessed 17-May-07.

[122] Management Sciences for Health. Provider's Guide to Quality and Culture. Cambridge, MA: MSH with Health Resource and Services Administration, Office of Minority Health and Bureau of Primary Health Care. Available at: http://erc.msh.org/ mainpage. $\mathrm{cfm}$ ?file=1.0. htm\&module= provider\&language $=$ English \&ggroup $=$ \&mgroup =. Accessed 24-May-07.

[123] Signorello LB, Hargreaves MK, Steinwandel MD, Zhang W, Cai Q, Schlundt DG, 
et al. Southern community cohort study: establishing a cohort to investigate health disparities. J Natl Med Assoc 2005;97:9729.

[124] Smith AL. Health policy and the coloring of an American male crisis: a perspective on community-based health services. Am J Public Health 2003;93:749-52.
[125] Gaskin DJ, Arbelaez JJ, Brown JR, Petras H, Wagner FA, Cooper LA. Examining racial and ethnic disparities in site of usual source of care. J Natl Med Assoc 2007; 99:22-30.

[126] Christman LK, Abdulla R, Jacobsen PB, Cantor AB, Mayhew DY, Thompson KS, et al. Colorectal cancer screening among a sample of community health center attendees. J Health Care Poor Underserved 2004;15:281-93.

[127] Atrash HK, Hunter MD. Health disparities in the United States: a continuing challenge. In: Satcher D, Pamies RJ, editors. Multicultural Medicine and Health Disparities. New York: McGraw Hill; 2006. p. 3-31. 